\title{
Emerging Information Technologies and Delivering of Service Quality to Air Passengers: Case of South African Own-Registered Airlines
}

\author{
Nicholas O. Mantey, Vannie Naidoo \\ University of KwaZulu-Natal, Durban, South Africa \\ manteyn@gmail.com, Naidoov@ukzn.ac.za
}

\begin{abstract}
Increasingly services to airline passengers have evolved into the digital and technological realms. This study examined the extent to which South African own-registered airlines (SAORA) utilize emerging information technologies in delivering service quality to air passengers. The acronym "SAORA" refers to Six South African own-registered airlines which was focus of this study. The research methodology adopted for this study was a descriptive approach focused on cross-sectional analysis. Using a quantitative research method and non-probability convenient sampling technique, primary data was collected from 684 passengers at O.R. Tambo International Airport in Johannesburg and King Shaka International Airport in Durban. The study revealed that by utilizing emerging technologies, SAORA stand to offer superior service quality to air passengers, thereby gaining competitive advantage, continuous patronage, loyalty and increased profitability.
\end{abstract}

Keywords: Configuration, intangibles, legacy systems, patronage, technologies

\section{Introduction}

This study examines Information and Communication Technologies (ICT) in the delivery of service quality in South African own-registered airlines (SAORA). Advances in Information technology systems in this $21^{\text {st }}$ Century have provided the opportunity for firms to deliver valued services to customers. Airlines now have numerous emerging technologies to deliver efficient and effective service quality to air passengers. While some of these technologies have been around for some time, others are emerging with improved features and capabilities. The significance of this study is that, it contributes towards advancement of academic knowledge, society, management, the global airline industry in general, and the airline industry in South Africa in particular. Therefore, this study has both theoretical and managerial significance. The subject matter of the study was considered from three perspectives: the extent to which emerging technologies improve service quality to airline passengers of South African own-registered airlines (SAORA); the gaps in the usage of emerging technologies in serving passengers of South African own-registered airlines (SAORA);establishing whether a significant relationship exists between passengers' service quality and the use of emerging technologies (ICT/CRM) in delivering efficient services to passengers of South African ownregistered airlines (SAORA).In conducting this study extensive literature was reviewed from both primary and secondary sources. This has enabled the study to unearth creative ideas and technological innovations from literature.

Currently, airline companies worldwide are using ICT for competitive advantage, and have become a strategic enabler for delivering efficient and faster service(s) to airline passengers (Esu and Anyadighibe, 2014:9). This study advocates that emerging information and communication technologies (ICT) and innovation tools, including customer relationship management (CRM) application software, be used to improve service quality in delivering services to airline passengers. Some of these emerging technologies are Customer Relationship Management (CRM), social media platforms, mobile/smartphones technologies, self-service technologies (SST), wireless communications platforms (Wi-Fi's), Radio Frequency Identification (RFID),E-commerce, BIG Data designed to analyze customers/passengers data, business intelligence/data warehousing applications, cloud computing platforms(designed to analyze and monitor passengers data), and m-commerce applications, mostly enabled by the Internet. Five of these emerging technologies for service quality delivery are highlighted in this article, namely CRM, social media platforms, SST, RFID, and mobile/smartphones. The South African own-registered airlines(SAORA) which were operational in South Africa as low cost airlines (LCA) and traditional airlines (TA) at the time of this study were: (1) Airline G (LCA), operating on domestic and regional routes, (2) Airline X (LCA/TA), operating on global, regional and domestic routes, (3) Airline C (LCA), operating on domestic routes, (4) Airline T (LCA) operating on domestic and regional routes, (5) 
Airline Y(TA)operating on global routes, and (6) Airline Z (LCA/TA) operating on domestic and regional routes (Luke and Walters, 2013:1-11).

Theoretical model: The main theoretical model that anchored this study was the SERVQUAL- Gaps model (Parasuraman et al., 1985:41-50; 1988:12-40; Lovelock and Wirtz, 2011:406). The scholars Parasuraman et al. (1988), in developing the SERVQUAL dimension model, conceptualized service quality constructs as: tangibles, reliability, responsiveness, assurance, and empathy focused on the customer. The SERVQUAL dimension model has served as the catalyst by which many researchers have either modified or developed new concepts (Chikwendu et al., 2012:118; Aydin and Yildirim, 2012:219 - 230) in the airline industry. In conducting this study three hypotheses were tested in respect of using emerging technologies to enhancing service quality in SAORA.

H1: Emerging technologies would improve service quality to airline passengers of South African ownregistered airlines (SAORA)

H2: Significant gaps exist in the usage of emerging technologies in serving SAORA airline passengers.

H3: A moderate negative significant relationship exists between passengers' service quality and the use of emerging technologies in delivering services to SAORA's passengers.

\section{Literature Review}

Scholars have emphasized the need for service firms to use information and communication technologies (ICT) systems as a strategic tool in response to customers' needs (Goktan and Miles, 2011:533). The subject airlines (SAORA), as with their peers in the industry across the globe, have embraced ICT in providing services to passengers. However, the fast pace at which technologies are emerging and modernizing business processes, particularly in the airlines (Elkhani, Soltani, and Jamshdi, 2013:109), suggests that airlines cannot afford to remain static. Several studies have confirmed that ICT has revolutionized the operational imperatives of most organizations, including the airline industry, thus impacting on service delivery to passengers (Esu and Anyadighibe, 2014:9; Cheng, Gibson, Carrillo and Fitch, 2011:509; Ojiako, 2012:584). Therefore, ICT is becoming a supportive base for competitive and strategic capability for the airline industry (Esu and Anyadighibe, 2014:9). Technology plays a crucial role in the re-configuration of the airline service value chain. The advent of the Internet, E-commerce and mobile communication has placed services in close proximity to the air passenger (Cheng et al., 2011:509). Therefore, ICT has improved certain challenges in the business environment and made firms dependable on ICT systems. In particular, ICT is becoming an indispensable tool of the airline industry because of the uniqueness of this mode of transportation, which thrives on speed of mobility, reliability, timeliness, comfort, efficiency, and other unique attributes (Esu and Anyadighibe, 2014:9-21). Information and communication technologies are considered as playing a fundamental role and significantly impacting the customers' experience (Edvardsson, Tronvoll, and Gruber, 2011:327). Ideally, there must be a mutual effort made by both customers and the service firm using ICT to enhance the service experience and service quality. Therefore, ICT creates a standardized service quality delivery, thereby inducing potential cost reductions for service firms and ensuring convenience for the customer during the service encounter (Edvardsson et al., 2011:327). However, the advances in ICT constantly affect the interface between the customer and the service provider, because of the introduction of new technologies (Gelderman, Ghijsen and van Diemen, 2011:414; Lin and Hsieh, 2012:100-109). While utilization of technologies and allied novelties may heighten passengers' expectations, and speedily embrace such technological innovations, they feel dissatisfied should the technology fail to provide the required service (Janawade, Bertrand, Léo, and Philippe, 2015:278). Additionally, ICT is ever more mandatory as a precondition for alliance arrangements between airlines; and it also makes possible the growth of pioneering delivery avenues for communicating with customers (Janawade et al., 2015:278). While ICT has made a considerable contribution to the success of many firms, there is the question of its actual effectiveness and exploitation in other firms (Ojiako, 2012: 584). However, Geum, Lee, Kang, and Park (2011:128) argued that, in order to ensure effective exploitation of ICT, managers should deploy effective strategies focusing mainly on delivery services, while simultaneously using real-time applications for servicing customers.

Emerging Technological Trends in Airlines: The fast pace of technologies in the airline industry may compel SAORA to enhance ICT systems, improving service offerings. Air passengers are becoming 
technologically savvy and demanding services (Lin and Hsieh, 2011:94-206) on electronicdevices rather than in the conventional way of providing face-to-face service and accessing of information ( $\mathrm{Ku}$ and Chen, 2015:465; Lock, Fattah, and Kirby, 2010:3). The attainment of future success by an airline depends in part on the airline's ability to utilise emerging technologies to deliver excellent customer experience. Such experience stimulates loyalty, while simultaneously "growing" employees' and operational competences (Lock et al.,2010:2). Thus,SAORA should embrace emerging technologies which enhance business operations (Esu and Anyadighibe, 2014:9; Ojiako, 2012:584). The five emerging technologies for service quality delivery in the airlines CRM, social media platforms, SST, RFID, and mobile/smartphones are discussed at this stage.

The first emerging technology discussed in this study is Customer Relations Management (CRM). The Customer Relations Management system, which is not new to the airline industry, is a critical technology with capability of managing the relationship between a service firm and the customer. These CRM systems enhance continuous relationships, customer patronage and loyalty, while at same time understanding the needs of the customer, and satisfying those needs (Kortlle and Kerller, 2012:42). The benefit of CRM to a service firm comprises upturn of revenues and profit growth, cheap marketing costs, concise decision-making as a consequence of better appreciation of customers' needs. Other benefits may result in customer satisfaction, retention, individualization of the product or the service and providing competitive advantage to the service firm (De Meyer and Mostert, 2011:80). Therefore, CRM software, combined with web-based applications, is becoming an indispensable tool for corporate strategy apropos of passengers for the airline industry, differentiating airlines in terms of service offerings from opposition airlines (Boland, Morrison, and O'Neill, 2002:1-4).

The second emerging technology which can conveniently be integrated into CRM is the social media applications. Scholars (Esu and Anyadighibe,2014:10; Edosomwan, Prakasan, Kouame, Watson, and Seymour, 2011:79-91) cited ways in which the social-media platforms and applications, enthused by micro-marketing techniques, are making inroads into the airline services' marketing space to offer customer satisfaction in the Nigerian airline industry. As quoted by Prabu (2012:1), the "social media is much more than just establishing mere presence. It is a revenue generating channel for many airlines, a medium that has helped PR teams at airline companies to cut down costs" (Esu and Anyadighibe, 2014:9). With the advent of social platforms, airline companies are now incorporating social-media platforms into their traditional CRM systems, thus enhancing communication and interaction between airline companies and passengers (Mills, and Plangger,2015:521). According to Menne and Halova (2013:32), the expression "Social CRM" is reasonably new. Its originators were Mohan, Choi, and Min (2008:237), who defined Social CRM as "the features of Web 2.0 and social networking with the current CRM Systems". Therefore, Social CRM is the combination of the "traditional CRM models and systems with the new Web 2.0 and social media capabilities of the Internet" (Menne and Halova, 2013:32). Strategically, "Social CRM" has become a tool with which to build stronger company and customer relationships (Faase, 2011:5). Effective deployment of these technological tools may potentially enable SAORA to provide more efficient service. Advances in technology and deploying of the Internet have enabled online communication between companies and consumers to move from Web 1.0 to Web 2.0 (Menne and Halova, 2013:2). The distinction between the two is that under Web 1.0, communication and the stream of information was one-sided, forwarded by the company to the consumer without enabling constructive feedback from the consumer (Menne and Halova, 2013:68). Under Web 2.0, online communication has developed from a simple one-sided to a two-sided stream; companies are now effortlessly receiving feedback from customers (Fuchs, Hofkirchneremail, Schafranekemail, Rafflemail, Sandovalemail, and Bichleremail, 2010:41). Web 2.0 is therefore the premise on which social-media platforms work, customers being able instantly to communicate with a company or an individual who can receive and send the necessary feedback (Fuchs et al., 2010:41).

Popular social media platforms include, amongst others, Facebook, Twitter, Google Plus, LinkedIn, Wikipedia, Pinterest, and others (Menne and Halova, 2013:2). From the customer or the air-passenger's perspective, the social-media platforms provide an opportunity for feedback comments/complaints to be made on the service-delivery experience, with the airline or service firm using the same platform on which to react to the comments/complaints (Mills and Plangger, 2015:530). All these may be combined with the conventional CRM architecture to enhance service quality to the passenger. The third emerging technology that has substantially 
impacted the airline industry and improved passenger service interacting experience is the self-service service technology (SST) (Geldermanet al.,2011:414; Lin and Hsieh, 2012:100-109). Services are multidimensional in character, therefore service firms utilize variety of competencies (Ojiako, 2012:585). Information technology systems drive these competencies, which in effect improve service delivery to the passenger. The advent of the Internet, E-commerce applications, and mobile communication systems, has strengthened the use of automated and self-managed technologies in the airline industry. Some airlines use ICTs to render outstanding service to passengers (Ojiako, 2012:585). While these technologies have substantially improved the service encounter and brought about savings, there has, nevertheless, been dissatisfaction and frustration for some customers in using these technologies (Gelderman et al., 2011:414; Lin and Hsieh, 2012:100-109). Indeed, a passenger now has the opportunity of processing a boarding pass using a self-service kiosk by means of self-service technologies (SST) located at airports, without needing assistance from airline staff (Lin and Hsieh, 2011:94-206).

The fourth emerging technology discussed in this study is Radio Frequency Identification (RFID). Radio Frequency Identification is an automated technology, which has capabilities of recognizing and tracking objects or persons from afar by means of electro-magnetic mechanisms (Mishra and Mishra, 2010:139; International Air Transport Association (IATA 2008:20). The RFID technology has been available for some time and is becoming popular in the airline industry because of its reputation for addressing issues relating to the handling of baggage (Roberti, 2013:1). According to Roberti (2013:1), baggage mishandling and lost items are a challenge to most airlines, costing the global airline industry US\$ 2.6 billion annually. Although RFID many not completely eradicate baggage mishandling, investment by airlines in this technology could generate substantial savings in baggage mishandling costs for the global industry (Roberti, 2013:1-2; IATA, 2008:20). The fifth emerging technology for airline services discussed in this study is about mobile and smartphones. Modern technologies have made inroads into the airline industry, especially with mobile technology. The use of mobile phones, smartphones, personal-assistance devices (PDAs), and many other mobile devices, are improving the way in which services are being delivered by some airline companies (Esu \&Anyadighibe, 2014: 9-21; Lock, Fattah, and Kirby, 2010:4). According to Lock et al. (2010:4) some of the examples of the latest services and applications (mobility 3.0) include personal-travel assistants, mobile marketing, mobileconcierge service, and mobile payment using smartphones, augmented reality and real-time business intelligence for airlines (Lock et al,,2010:4). Airlines using innovative technologies include American Airlines, Air France, and Emirates Airlines, to mention a few. The American Airlines (AA) Multichannel Mobile Web Capabilities, for example, makes it possible for American Airlines to be in contact with passengers while inflight (Lock et al.,2010:6). Increasingly, more passengers are turning to smartphones/mobile communication devices for information, constantly desiring access to information (Ku and Chen 2015: 465). Some airlines are already providing information to passengers, confirming bookings, providing information on conditions at the airports, check-in, boarding, and departure times. These technologies are consistently sending information to the passenger on a real-time basis, thus improving the service quality to the passengers (Castro, Atkinson, and Ezell, 2010:25). Real-time customer service using the social media is becoming critical in finding a solution to passengers' problems (Geum et al., 2011:128).

According to airline industry experts, the smartphone holds the future for enriched service to passengers who require information at the touch of a device (Castro et al., 2010:25; Ku and Chen, 2015:465). The average passenger is so connected to technological devices that a passenger may be considered a "digital traveler" (SITA, 2015:1). Using mobile technologies and devices, passengers can check in per iPhone, BlackBerry, iPad, tablet, other brand mobile phones, smartphones, and a range of devices offering various capabilities. For example, Emirates Airlines appears to be the vanguard in online mobile novelty, using its Emirates.com enabled for smartphones (Lock et al., 2010:6). "Airlines and airports will continue to grow existing mobile offerings centered on flight status, purchase services, and retail offers. But unquestionably, the new frontier in passenger mobile services will be consumer relationships and personalization" (Pickford, 2015:6). According to SITA, a new air-travel survey entitled "The future is personal" provides an in-depth examination of IT trend surveys. The next level of expectation from passengers is for mobility and "personal touch" or "me-centric", that is, the satisfying of ever-increasing expectations of the traveler at a personal level (Pickford, 2015:6). 


\section{Methodology}

The study employed a survey-based research technique. This was adopted, using a descriptive research approach focused on cross-sectional analysis (sample survey). This study is therefore quantitative in nature, using primary data. A five-point Likert scale questionnaire was developed with influences from the SERVQUAL- Gaps model for conducting the survey. The questionnaire was adapted to the SERVQUAL instrument developed by Parasuraman, Berry and Zeithmal (1985). The target population for this study consisted of passengers (domestic and international) totaling seventeen million four hundred thousand passengers (ACSA annual report, 2014:114) who travelled through the O.R. Tambo airport in Johannesburg and the King Shaka airport in Durban. The sampling method used for this study was non-probability convenience sampling- a type of non-probability sampling in which people are sampled because they are "convenient" sources of data for the researcher (Mantey, 2015:150; Sekaran and Bougie, 2013:252; Mostert, De Meyer and van Rensburg, 2009:118). The sample for this study was seven hundred SAORA passengers selected from the target population. In all, seven hundred questionnaires were directly distributed at the O.R. Tambo airport in Johannesburg, and the King Shaka airport in Durban. The response rate for the data collection was $97.71 \%$. The instrument was subjected to rigorous validation and reliability processes: through internal consistency review, Cronbach alpha testing, pilot testing, content validity and expert opinions. The overall Cronbach's alpha coefficient test was calculated as 0.900 which was within the expected levels of 0.00 to 1 (Sekaran and Bougie, 2013:228). Cronbach alpha testing was performed on the data reliability of this study and the results were 0.810 which was within the range of 0.00 to 1 , therefore the data was considered reliable. This study was conducted taking into consideration the ethical requirements of the University of KwaZulu- Natal.

\section{Results and Discussion}

The following were the empirical findings of the study, starting with the socio-demographic information as per Table 1).

Table 1: Distribution of Socio-demographic Information

\begin{tabular}{lll}
\hline Variables & Frequency & Percentage \\
\hline Gender & & \\
Female & 312 & 45.6 \\
Male & 372 & 54.4 \\
Total & 684 & 100.0 \\
Race & & \\
African & 434 & 63.5 \\
Colored & 93 & 13.6 \\
Indian & 67 & 9.8 \\
White & 90 & 13.2 \\
Total & 684 & 100.0 \\
Age group & & \\
18 - 30 years & 213 & 31.1 \\
31 - 40 years & 273 & 39.9 \\
41 - 50 years & 137 & 20.0 \\
51 - 60 years & 43 & 6.3 \\
$>$ T0 years & 18 & 2.6 \\
Total & 684 & 100.0 \\
Monthly income & & \\
Less than R50001 & 603 & 88.2 \\
50001 - 100000 & 54 & 7.9 \\
>100000 & 27 & 3.9 \\
Total & 684 & 100.0 \\
Education & & \\
Primary & 14 & 2.0 \\
\hline
\end{tabular}




\begin{tabular}{lll}
\hline Secondary & 93 & 13.6 \\
Tertiary/University & 577 & 84.4 \\
Total & 684 & 100.0 \\
\hline
\end{tabular}

(Source: Mantey 2015:156)

Socio- demographic findings indicated that, of the passengers who participated in the study, 64\% were Africans, the majority of participants. The results showed that $46 \%$ of the survey's participants were female, and (54\%) were male. Colored comprised 13.6\%, Indians 9.8\%, and Whites constituted $13.2 \%$ of the survey. The socio-demographic results also revealed that most SAORA's passengers (71\%) were in the younger age bracket (below 40). A large number of the respondent passengers (84\%) had attended tertiary institutions. The results also highlighted that about half of the passengers (47\%), were at the middle-income level. The implication of these findings is that the majority of participants who took part in this survey fall within the middle-class, earning a reasonable income of up to R50 000 per month, and having university-level education. The middle-class and the youth tend to have appetite for consuming technology services (Lock et al.,2010:4; Pickford, 2015:6). Consequently, SAORA should consider investing in emerging technologies and application systems in order to deliver excellent service quality to passengers in South Africa.

Emerging technologies and improvement of service quality: In achieving this research objective passenger were asked whether emerging information technologies would greatly improve SAORA service quality to them. The results are depicted Figure 1 below.

Figure 1: Emerging technologies and improvement of service quality

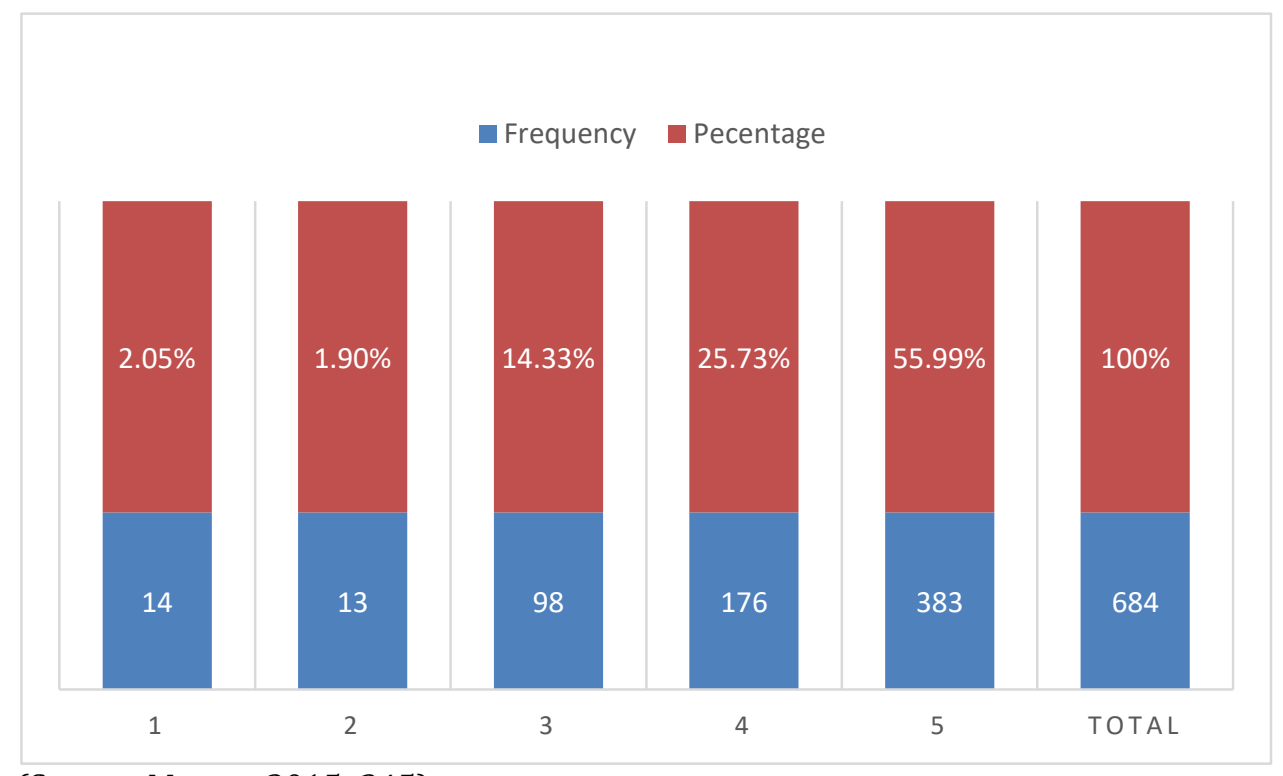

(Source: Mantey 2015: 245)

The results were that $14.33 \%$ of the respondents were neutral about the statement. However, $55.99 \%$ of the respondents strongly agreed with the statement. Another $25.73 \%$ agreed with the statement. A small number of passengers $1.90 \%$ disagreed and $2.05 \%$ strongly disagreed with the statement. Therefore, the finding was that effectively $81 \%$ of SAORA passengers conceded that emerging information technologies would greatly improve delivery of service quality to them. This lead to the hypothesis that:

H1: Emerging technologies would improve service quality to airline passengers of South African ownregistered airlines (SAORA)

There is ample literature to support the above hypothesis that ICT has the capacity to improve service quality to airline passengers (Elkhani et al., 2013: 109-117; Esu and Anyadighibe, 2014: 9-21; Ku and Chen, 2015:465). Therefore, based on the findings of this study and the literature the hypothesis is valid and accepted. 
Descriptive Statistics-Emerging technologies gaps and service quality: Descriptive data manipulations were conducted to determine the relationship in the gap scores and ICT within the context of passengers' expectations and perceptions towards ICT (Tables 2 \&3). The ICT expectations level from passengers were determined by evaluating the specific attributes relating to ICT in the questionnaire as depicted in Table 2. The attributed statement AS 7 under the tangibility dimension asked whether SAORA have efficient information technology systems to deliver efficient services to passengers. AS 9, also under tangibility, was about whether SAORA have in-flight communication facilities (internet/email/fax/phone) for passengers. AS 24 under the responsiveness dimension was about whether online booking and websites of SAORA were user-friendly for ticket booking. The data manipulation depicted in Table 2 was as follows:

Table 2: ICT Expectations attributes

\begin{tabular}{llllllll}
\hline Expectations & SD & D & N & A & SA & Mean Score (m) & Standard Deviation (SD) \\
\hline AS 7 & & & & & & & \\
AS9 & 1.3 & 0.9 & 5.1 & 15.6 & 77 & 4.66 & 0.733 \\
AS24 & 1.6 & 2.8 & 8.3 & 17.3 & 70 & 4.53 & 0.888 \\
\hline
\end{tabular}

$\mathrm{SD}=$ strongly disagree, $\mathrm{D}=$ Disagree, $\mathrm{N}=$ Neutral, $\mathrm{A}=$ Agree, $\mathrm{SA}=$ Strongly Agree

(Source: Mantey, 2015:248)

The finding was that the mean score for all the expectation statements in respect of ICT as set out in Table 2 were more than four $(m=>4)$. In respect of attribute AS7 the mean score was $m=4.66$ and a SD 0.733 while for attribute AS 9 the mean score was $m=4.53$ and SD 0.888. The attribute AS24 had a mean score of $\mathrm{m}=4.67$ and a SD 0.71. In Table 3, the Perceptions mean scores were slightly above three $(\mathrm{m}=>3)$ for the attributes. The mean score for attribute AS 7 was $m=3.174$ with SD 1.078. The attributes AS 9 and AS 24 recorded $\mathrm{m}=3.034$ and SD 1.074 and $\mathrm{m}=3.148$; SD1.027 respectively. The Table 3 also shows the gap differences between ICT perceptions and expectations gaps using the mean and standard deviation gaps (P-E gap).

Table 3: ICT Perceptions and Expectations Gapsat SAORA

\begin{tabular}{llllllllll} 
Perceptions & SD & D & N & A & SA & $\begin{array}{l}\text { Mean } \\
\text { Score } \\
\text { (m) }\end{array}$ & $\begin{array}{l}\text { Standard } \\
\text { Deviation } \\
\text { (SD) }\end{array}$ & $\begin{array}{l}\text { P-E (Gap) } \\
\text { (Mean) } \\
\text { (m) }\end{array}$ & $\begin{array}{l}\text { P-E } \\
\text { (Gap) } \\
\text { (St Dev) } \\
\text { (SD) }\end{array}$ \\
\hline AS7 & 7.2 & 16.7 & 40.5 & 23 & 12.7 & 3.174 & 1.078 & -1.488 & 0.345 \\
AS9 & 8.8 & 18.1 & 44.2 & 19.4 & 9.5 & 3.034 & 1.074 & -1.491 & 0.1863 \\
AS24 & 4.2 & 22.2 & 39.5 & 22.7 & 11.4 & 3.148 & 1.027 & -1.526 & 0.317 \\
\hline
\end{tabular}

SD= strongly disagree, $D=$ Disagree, $N=$ Neutral, $A=$ Agree, $S A=$ Strongly Agree

(Source: Mantey 2015:168)

The ICT Gap scores in Table 3 was computed by using the formula: Service Quality $(\mathrm{Q})=$ Perception (P) Expectation (E) (Parasuraman et al., 1985, 1988; Lovelock and Wirtz, 2011:406; Naidoo, 2015: 45). The gap score under AS 7 as per Table 3 was $M=1.488$ with SD 0.345. The gap score under AS 9 is $M=1.491$ with SD 0.1863 . With regard to AS24 the gap score was $M=1.526$ with SD 0.317). The negative mean score results between perceptions and expectations revealed that there were significant gaps in the usage of ICT, and that participants (SAORA's passengers) were unhappy or dissatisfied with service quality in respect of ICT. This leads to a hypothesis that:

H2: Significant gaps exist in the usage of emerging technologies in serving SAORA airline passengers.

In the light of literature this finding means that user-friendly systems, including website usage, were crucial in impacting on service quality (Ku and Chen, 2015:465). Prior studies reveal that user-friendly systems bring satisfaction to customers in terms of service quality evaluation (Ku and Chen, 2015:465). Airlines are now using e-ticketing, which may be processed via the Internet and the E-commerce platforms. This has drastically reduced transaction costs to the airlines while enhancing convenience to the passenger. While 
some passengers still use conventional ticket agents for bookings and purchase of tickets, e-ticketing and credit cards may be processed online, tickets being purchased in real-time (Geum et al., 2011:128). Therefore, the above hypothesis is valid and SAORA should consider strategies to bridge or meet the emerging information technologies gap.

Inferential Statistics-Relationship between emerging technologies and Service Quality delivery to passengers: The study attempted to establish the relationship between SAORA's service quality delivery and the use of emerging technology in delivering efficient services to passengers. Inferential statistics were manipulated. The Kendall's tau-b $(\mathrm{Tb})$ correlation coefficient was used to establish the association between two independent variables- the use of emerging technologies and service quality. The computation of Kendall's tau-b $(T b)$ correlation coefficient (orKendall's tau-b) in data manipulation and analysis, is considered as a non-parametric measurement tool used to determine the strength and direction of the association that exists between two variables (Lund and Lund n.y.). It is especially ideal when the measurement is being done on an ordinal scale with dependent and independent variables. It is often used in place of Pearson's product-moment correlation or Spearman's rank-order correlation coefficient (Lund and Lund n.y.). Therefore, the Kendall's tau_b correlation was used to establish the relationship between the variables. Table 4 below shows this relationship.

Table 4: Emerging Technologies and Services quality delivery to passengers

\begin{tabular}{|c|c|c|c|c|}
\hline \multicolumn{5}{|l|}{ Correlations } \\
\hline & & & Q 3.5 & Gap of ICT \\
\hline \multirow[t]{6}{*}{ Kendall's tau_b } & Q 3.5 & Correlation Coefficient & 1.000 & $-.222^{* *}$ \\
\hline & & Sig. (2-tailed) & & .000 \\
\hline & & $\mathrm{N}$ & 684 & 684 \\
\hline & Gap of ICT & Correlation Coefficient & $-.222^{* *}$ & 1.000 \\
\hline & & Sig. (2-tailed) & .000 & \\
\hline & & $\mathrm{N}$ & 684 & 684 \\
\hline
\end{tabular}

Source: Mantey 2015:169

The correlation analysis in Table 4 showed that a moderately negative correlation exists between service quality and ICT $(r=-0.222, p<0.01)$. The moderately negative correlation gap score of $r=-0.222$ and $p<0.01$ means that emerging ICT technologies were not being fully utilized to deliver services to passengers. Table 4 confirms that there were significant gaps in using ICT for service delivery at SAORA. Consequently, a hypothesis is formulated that:

H3: A moderate negative significant relationship exists between passengers' service quality and the use of emerging technologies in delivering services to SAORA's passengers.

In the context of literature, air passengers are becoming technologically savvy, demanding services Lin and Hsieh (2011:94-206) on electronic devices rather than in the conventional manner of face-to-face service and in accessing information (Ku and Chen, 2015:465; Lock et al., 2010:3). In the literature ample information is provided on how emerging technologies may potentially improve service quality delivery (Cheng et al., 2011:509; Castro et al., 2010; Edosomwan, Praksan, Kouame, Watson, Seymour, 2011:79-91; Elkhani et al., 2013:109; Ojiako, 2012:584). Strategic adoption of emerging technologies may potentially improve SAORA's service quality. The socio-demographic information in this study, as discussed above, points to the fact that SAORA has a young generation of passengers who are predisposed to using technological devices. The social media channel and mobile technologic means of disseminating information is a modern convenience to passengers, proving to be more progressive and satisfying to society (Esu and Anyadighibe, 2014:100; Jiako, 2012:584). According to Esu and Anyadighibe (2014:20), the 21 st century airline should incorporate knowledge-based economies, social-media technologies and micro-marketing into the traditional marketing strategies of airlines in order to satisfy service expectations of passengers. Given that a large percentage of SAORA's passengers (as per the socio-demographic information in Table 1), fall within the younger generation bracket (71\% were 40 years or younger; educated (84\%); and earning an income of up to R50 000 
per month) thus, investing in emerging technologies to provide better and faster service to these passengers should be regarded as a proactive strategic move, in accordance with their social status. These younger generation and middle-aged passengers of SAORA are likely to own electronic devices and may demand personalized services on electronic devices (Pickford 2015:6). Based on the findings of the study, supported by existing literature the hypothesis $H 3$ is accepted. This study strongly maintains that SAORA's adoption of new technologies will go a long way towards improving service quality in South African airlines (Naidoo, 2015:98).

Results of prior studies: Globally, some scholars have researched the subject, although from different perspectives (Tolpa, 2012; Pickford, 2015, Buhalis, 2003) among others. The research results of the present study differ from prior studies conducted by the above-mentioned scholars. The results of the present study specifically highlight on the usage of emerging technologies in delivery service quality to air passengers in South Africa. However, Tolpa's research underlined the importance of using systems to perform critical functions of airline processes such as ticket purchases, pre-flight procedures, check-in, airport services, departure, in-flight and arrival services, and baggage delivery services to passengers (Tolpa, 2012:62). While Pickford's study was on emerging technologies, the emphasis was on future utilization of emerging technologies in the global airline industry. Buhalis (2003), focused on delivering value to air passengers with particular emphasis on strategic and tactical application of ICT in e-airline environment. Therefore, comparatively all these studies revealed different findings/results.

The significant findings of the present study are : (1) effectively $81 \%$ of SAORA passengers conceded that emerging information technologies greatly improved delivery of services to them; (2) Significant gaps existed in the application of emerging technologies in serving SAORA passengers;(3) a moderately negative significant relationship existed between passengers' service quality and the utilization of emerging technologies in delivering services to SAORA's passengers, and (4) 71\% of SAORA passengers fall within the younger generation bracket (40 years or younger; educated at tertiary level (84\%); and earning an income of up to (R50 000 per month). Potentially, the younger generations are becoming technologically savvy, and may demand airline services on electronic devices. This study revealed that by depending on emerging technologies, SAORA stand to offer superior service quality to air passengers, thereby gaining competitive advantage, continuous patronage, loyalty and increased profitability.

Theoretical and Managerial significance: The theoretical significance of this study is its contribution towards the improvement of academic knowledge and providing new information. From South African perspective, there is dearth of research in the subject area, and this study has contributed in bridging the research gap. This study reveals that SAORA should redesign their service packages, embedding them with emerging ICT applications, for efficient and effective delivery of services to all passengers. This study takes the stand that it is critical for SAORA to invest and integrate emerging technologies into their legacy systems to effectively deliver service quality to passengers. From managerial and strategic marketing perspective, SAORA management could use information from this study to design technological-induced services for young people, knowing the socio-demographics of passengers in South Africa. Technology has transformed the airline industry worldwide. South Africa owned registered airlines should come on board and be abreast with new technological changes that directly impact customers' satisfaction in terms of airline service quality delivery. Information technology systems, RFID systems, self-service systems, the Internet, and mobile technologies devices (including mobile and smartphones), will compel airline companies to review their delivery efforts. The ability of SAORA's adaptation to change, supported by technology will determine their level of competitiveness in the airline industry (Edosomwan et al., 2011:79-91).

Recommendations: The following recommendations are proposed, based on the findings of this study and the underlying reviewed literature: 


\begin{tabular}{l} 
Journal of Economics and Behavioral Studies (ISSN: 2220-6140) \\
Vol. 10, No. 1, pp. 194-206, February 2018 \\
\hline \hline
\end{tabular}

Table 5: Summary of recommendations

\begin{tabular}{|c|c|}
\hline Recommendations & Application areas \\
\hline Technology-enabled devices & $\begin{array}{l}\text { Airline staff should provide prompt service at check-in- terminals by using } \\
\text { technology-enabled devices. } \\
\text { Passengers should be encouraged to use self-service kiosks currently } \\
\text { installed at South Africa airports,in order to improveservices at check-in- } \\
\text { terminals. }\end{array}$ \\
\hline
\end{tabular}

Customerfeedback system SAORA should provide an effective and efficient customer feedback (CFS) system (CFS) so that passengerscould receive real-time solutions to their complaints on elcectronic devices.

UpgradingCRM systems

SAORA shouldupgrade their current CRM systems to "social CRM" system status, by synchronising these systems with passengers' mobile and smartphones.

SAORA should also consider upgrading their CRM systems, by adding social-media applications/upgrades. This will ensure that passengerswill be able toprovide instant or real-time feedback information to SAORA on complaints, suggestions, appreciation, inter alia.SAORA should consider using emerging technologies combined with bespoke customer relationship management systems and application systems to deliver personalised or individualised services to passengers.

Legacy systems

This study strongly recommends that SAORA management should consider upgrading their legacy systems (old systems), including CRM systems, by deploying emerging ICT devices and applications to efficiently process passengers' transactions.

For example, passengers should be able to make bookings, check-ins, paymenst, and check boarding passes by using their mobile and smartphones.

Some international airlines are using mobile and smartphones when boarding passengers (Castro et al., 2010: 25).

Interfaced Systems

Special applications (software) could be developed and interfaced with the existing legacy systems of SAORA to disseminate information to passengers in real-time mode.

While SAORA are using the short message service (SMS) to send information to passengers, not all domestic airlines send SMSes to passengers in South Africa.

The youth and electronic devices

The youth and the middle class will continue to consume services via electronic devices, and SAORA Management should strategise around the findings of this study and provide certain aspects of airline services via electronic devices.

Synchronisingpresent systems

The starting point for SAORA is to synchronise their present systems with emerging technologies, providing user-friendly websites, which passengers could visit on their mobile and smartphones, to make bookings and purchase tickets without difficulty.

Mobile and smart phone applications could be used to conduct procedures relating to the pre-flight, check-in, and departure procedures.

Passengers should be able to check-in and obtain a boarding pass via their mobile and smartphone as is currently being done by some international 


\begin{tabular}{|c|c|}
\hline \multicolumn{2}{|c|}{$\begin{array}{l}\text { Journal of Economics and Behavioral Studies (ISSN: 2220-6140) } \\
\text { Vol. 10, No. 1, pp. 194-206, February } 2018 \\
\end{array}$} \\
\hline RFID technology & $\begin{array}{l}\text { airlines (Castroet al., 2010:25). } \\
\text { RFID technology could be deployed by SAORA to secure passengers' } \\
\text { luggage and ensure effective monitoring. }\end{array}$ \\
\hline Entertainment & $\begin{array}{l}\text { SAORA should consider upgrading their current in-flight systems to } \\
\text { ensure that passengers are able to use and enjoy entertainment on board } \\
\text { the aircraft. }\end{array}$ \\
\hline Morden Aircrafts & $\begin{array}{l}\text { Emerging multimedia facilities could be installed on board the aircraft to } \\
\text { enhance passengers' travelling experience, especially on long-distance } \\
\text { international routes. } \\
\text { Passengers in this era of information technology wish to be constantly } \\
\text { connected to electronic devices whether on the ground or in the air } \\
\text { (Pickford, 2015:6; 2014:1). Therefore, SAORA should consider purchasing } \\
\text { modern aircrafts which allow passengers to use their electronic devices } \\
\text { in-sflight without interfering with the operation of the aircrafts. }\end{array}$ \\
\hline
\end{tabular}

Limitations \& Future research: The limitation of the research methodology was that only a few passengers from South African own-registered airlines participated in the study. However, the data used for the study was valid, therefore the research is credible. Another limitation was that South African own-registered airlines were not willing to support this study. This situation delayed the data collection process. However, the sampled respondents were enthusiastic about the study and completed the questionnaire. Future research area is that, researchers should consider conducting comparative studies on the respective of South African own-registered airlines to determine which airline has the best ICT systems to deliver efficient and effective services to air passengers. This research could be conducted with full co-operation and support from Management of the respective airlines.

\section{Conclusion}

In conclusion, emerging information technology systems, RFID systems, CRM systems, self-service systems, the Internet, and mobile technologies devices (including mobile and smartphones and others not mentioned in this study), should compel airline companies to review their service delivery efforts. In order to be on top of their game, SAORA should consider enhancing and integrating some of these technologies into their existing systems. Extensive narratives from literature were examined with the emphasis being placed on service quality in airlines using ICT as a tool. Excellent service quality delivery should be combined with emerging technologies as a strategic tool for competitive advantage. Using modern technologies to support their business processes, SAORA stands a better chance of offering a superior quality service to their passengers, thereby gaining continuous patronage and loyalty, not to mention increased profitability.

\section{References}

ACSA. (2014). Airport Company of South Africa. Annual reports. http://www.acsa.co.za/FinancialResults/2014 20Integrated\%20Annual\%20Report\%202014.pdf

Aydin, K. \& Yildirim, S. (2012). The measurement of service quality with SERVQUAL for different domestic airline firms in turkey. Serbian Journal of Management, 7(2) $219-230$.

Boland, D., Morrison, D. \& O'neill, S. (2002). The future of CRM in the airline industry: a new paradigm for customer management. Somers, New York: IBM Institute for Business Value

Buhalis D. (2003). eAirlines: Strategic and tactical use of ICTs in the airline industryhttp://epubs.surrey.ac.uk/1120/1/fulltext.pdf

Castro, D., Atkinson, R. \& Ezell, S. (2010). Embracing the Self-Service Economy, the information technology and innovation foundation (ITIF) Washington, U.S.A. Available at: www.itif.org

Cheng, L., Gibson, M., Carrillo, E. \& Fitch, G. (2011). A technology-centric framework for investigating business operations. Industrial Management Data Systems, 111(4)509-30. 
Chikwendu, D.U., Ejem, E. \& Ezenwa, A. (2012). Evaluation of service quality of Nigerian airline using SERVQUAL model. Journal of Hospitability Management, and Tourism, 3(6), 117-126. http://academicjournals.org/JHMT

De Meyer, C. F. \& Mostert, P. G. (2011). The influence of passenger satisfaction on relationship formation in the South African domestic airline industry. South African Journal of Business Management, 4, 42- 79.

Elkhani, N., Soltani, S. \& Jamshdi, M. H. M. (2013). Examining a hybrid model for e-satisfaction and e-loyalty to e-ticketing on airline websites. Journal of air transport management, 102(1), 109-117. http://ijcsi.org/papers/IJCSI-10-2-1-109-117.pdf

Edosomwan, S., Praksan, S. K., Kouame, D., Watson, J. \& Seymour, T. (2011). The history of social media and its impact on business. Journal of applied Management and Entrepreneurship, 16(3), 79-91

Edvardsson, B., Tronvoll, B. \& Gruber, T. (2011). Expanding understanding of service exchange and value cocreation: a social construction approach. Journal of the Academy of Marketing Science, 39(2), 327-397.

Esu, B. B. \& Anyadighibe, J. A. (2014). Social media Micromarketing and customers' satisfaction of domestic airlines in Nigeria. American Journal of Marketing Research, 3(1), 9-21

Faase, R. (2011). Web 2.0 in the CRM domain: Defining social CRM. International Journal of Electronic Customer Relationship Management, 5(1),1-22.

Fuchs, C., Hofkirchneremail, W., Schafranekemail, M., Rafflemail, C., Sandovalemail, M. \& Bichleremail, R. (2010). Theoretical foundations of the Web: Cognition, communication, and communication. Towards an understanding of Web 1.0, 2.0, 3.0. Future Internet, 2(1), 41-59.

Gelderman, C., Ghijsen, P. \& Van Diemen, R. (2011). Choosing self-service technologies or interpersonal services - the impact of situational factors and technology-related attitudes. Journal of Retailing and Consumer Services, 18(5), 414-21.

Geum, Y., Lee, S., Kang, D. \& Park, Y. (2011). Technology road mapping for technology-based product-service integration: a case study. Journal of Engineering and Technology Management, 28(3), 128-46

Goktan, A. B. \& Miles, G. (2011). Innovation speed and radicalness: Are they inversely related? Management Decision, 49(4), 533-547

International Air Transport Association (IATA). (2008). Annual report 2008www.iata.org/about/Documents/iata-\%20annual-\%20report-\%202008.pdf

Janawade, V., Bertrand, D., Léo, P. Y. \& Philippe, J. (2015). Assessing 'meta-services': customer's perceived value and behavior. The Service Industries Journal, 35(5), 275-295. http://dx.doi.org/10.1080/02642069.2015.1002480

Kotler, P. \& Keller, K. L. (2012). Marketing Management 14th edition. Pearson Education, New Jersey.

Ku, E. C. S. \& Chen, C. D. (2015). Cultivating travelers' revisit intention to e-tourism service: the moderating effect of website interactivity. Behavior \& Information Technology, 34(5), 465-478 http://dx.doi.org/10.1080/0144929X.2014.978376

Lin, H. C. K. \& Hsieh, M. C. (2012). The Establishment and Usability Evaluation on a Markerless AR-based Hairstyle Simulation System. International Journal of Online Pedagogy and course design, 2(2) 100109.

Lin, J. \& Hsieh, P. (2011). Assessing the self-service technology encounters: development and validation of SSTQUAL scale. Journal of Retailing, 87(2), 194-206.

Lock, H., Fattah, A. \& Kirby, S. (2010). Airline of the Future: Smart Mobility Strategies that will transform the Industry, Point of View and Cisco Internet Business Solutions Group (IBSG), 1-16, http://www.cisco.com/go/ibsg

Lovelock, C. \& Wirtz, J. (2011). Services Marketing people, Technology, Strategy. $7^{\text {th }}$ edition, Pearson Education, Inc., New Jersey.

Luke, R. \& Walters, J.(2013). Overview of the developments in the domestic airline industry in South Africa since market deregulation. Journal of Transport and Supply Chain Management,7(1), 117, 1- 11.

Lund, A. \& Lund M. (n.y.) Kendall's tau-b $(T b)$ correlation coefficient Internet: https://statistics.laerd.com/spss-tutorials/kendalls-tau-b-using-spss-statistics.php

Mantey N. O. (2015).Passengers' perceptions and expectations towards service quality of airlines owned by South Africa. Durban: University of KwaZulu-Natal. (PhD thesis).

Menne \& Halova. (2013). Using Social CRM to influence Customer Service and Loyalty: A Perspective in the Airline Industry (Master Thesis) http://lup.lub.lu.se/luur/download?func= downloadFile\&recordOId=3878772\&fileOId=3878782. 
Mobility in Airlines (nod)Information Services Group U.S.A http://www.isg-one.com/web/research-insights/

Mills, A. J. \& Plangger, K. (2015). Social media strategy for online service brands. The Service Industries Journal, 35(10), 521-536. http://dx.doi.org/10.1080/02642069.2015.1043277.

Mishra, D. \& Mishra, A. (2010). Improving Baggage Tracking, Security and Customer Services with RFID in the Airline Industry. Acta Polytechnica Hungarica, 7(2), 139 -154.

Mostert, P. G., De Meyer, C. F. \& Van Rensburg, L. R. J. (2009). The influence of service failure and service recovery on airline passengers' relationships with domestic airlines: an exploratory study. Southern African Business Review, 13(2), 118-140.

Mohan, S., Choi, E. \& Min, D. (2008). Conceptual modelling of enterprise application system using social networking and Web 2.0 'social CRM system, paper presented at 2008 International Conference on Convergence and Hybrid Information Technology, Busan, Korea: 237-244.

Naidoo, V. (2015). A comparative study between staff and student perceptions on service quality. Journal of Contemporary Management. Department of higher education and training accredited ISBN 1815$7440,12,40-60$.

Ojiako, U. (2012). Using IS/IT to enhance service delivery. Industrial Management and Data Systems, 112(4), 584-599.

Parasuraman, A., Zeithaml, V. A. \& Berry, L. L. (1985). A conceptual model of service quality and its implications for future research. Journal of Marketing, 49(4), 41-50.

Parasuraman, A., Zeithaml, V. \& Berry, L. L. (1988). SERVQUAL: a multiple-item scale for measuring consumer perceptions of service quality. Journal of Retailing, 64(3), 12-40.

Prabu, K. (2012). Social media in airline industry: How airlines are leveraging the platform with their creativity. Http: www. nicesuitenichesuit.blog.spot.com

Pickford, N. (2015). Air Transport. IT Review Issue, 1-2015, SITA. https://www.sita.aero/globalassets/docs/air-transport-it-review/air-transport-it-review-issue-12015.pdf.

Pickford, N. (2014). Survey report conducted by SITA in 2014. http://www.passengerterminaltoday.com/viewnews.php?NewsID=57883.

Roberti, M. (2013). Airlines could benefit from RFID-enabled baggage handling, RFID, Journalhttp://www.rfidjournal.com/articles/pdf?10992.

Sekaran, U. \& Bougie, R. (2013). Research Methods for Business -Skill- Building Approach. $6^{\text {th }}$ ed. Wiley. U.K.

SITA (2015). IT's all about me"http://www.sita.aero/resources/air-transport-it-review/ready-for-theconnected-traveler/its-all-about-me.

Tolpa, E. (2012). Measuring Customer Expectations of Service Quality: case Airline Industry AALTO University School of Economics Department of Information and Service Economy (Master's thesis). 